\title{
EVALUASI KELAYAKAN FINANSIAL DAN KEUNTUNGAN PETERNAKAN AYAM RAS PETELUR PT SPU DAN AF DI KECAMATAN JATI AGUNG KABUPATEN LAMPUNG SELATAN
}

\author{
(Financial Feasibility Evaluation and Profitability Analysis of Layer Farming at PT SPU and AF \\ in Jati Agung Subdistrict of South Lampung Regency)
}

Danang Wicaksono, Wan Abbas Zakaria, Sudarma Widjaya

Jurusan Agribisnis, Fakulas Pertanian, Universitas Lampung, Jl. Prof. Dr. Soemantri Brodjonegoro No. 1 Bandar Lampung 35141, e-mail: danangwcksn@gmail.com

\begin{abstract}
This research aims to know the financial feasibility evaluation and profitability at PT. SPU and AF in Jati Agung Sub-district of South Lampung Regency. This research location was selected purposively. The data was collected in October - December 2018. The research method used was comparative study. This research compares between PT SPU with AF. The respondents include the owners of each layer farm. The data analysis method used was qualitative and quantitative descriptive analysis. The data analysis using profit analysis, Internal Rate of Return (IRR), Net Present Value (NPV), Payback Period (PP), Gross Benefit Cost Ratio (Gross B/C), Net Benefit Cost Ratio (Net B/C). with interest rate of 9 percent. The result showed that PT SPU and AF was profitable and can con continue to be developed. Financially, the business is still viable because the NPV and Net B/C is higher than 1, and the value of IRR is higher than the interest rate.
\end{abstract}

Key words: agribusiness system, layer, profit

\section{PENDAHULUAN}

Sektor pertanian memiliki beberapa subsektor yang terdiri dari subsektor tanaman pangan dan hortikultura, subsektor perkebunan, subsektor kehutanan, subsektor peternakan, dan subsektor perikanan. Subsektor peternakan memiliki kontribusi untuk meningkatkan ketahanan pangan dan memenuhi kebutuhan protein hewani. Salah satu komoditas peternakan sebagai sumber protein hewani adalah telur ayam. Telur ayam merupakan bahan pangan yang padat akan gizi yang baik dan lebih murah dibandingkan dengan produk ternak lainnya, sehingga telur merupakan makanan yang ideal dan mudah untuk didapatkan (Direktorat Jenderal Peternakan dan Kesehatan Hewan 2010).

Produksi telur di Provinsi Lampung menempati urutan kesebelas secara nasional. Hal itu menunjukkan bahwa Provinsi Lampung merupakan wilayah potensial untuk usaha peternakan ayam ras petelur. Lampung Selatan merupakan kabupaten dengan populasi ayam ras petelur tertinggi di Provinsi Lampung. Populasi tersebut merupakan akumulasi dari populasi ayam ras petelur di seluruh kecamatan yang ada di Kabupaten Lampung Selatan. Kecamatan Jati Agung merupakan sentra peternakan ayam ras petelur karena memiliki populasi ayam ras petelur tertinggi di Lampung Selatan yaitu 1.077.000 ekor (Badan Pusat Statistik 2017)

Dalam agribisnis peternakan ayam ras petelur, pengadaan sarana produksi berkaitan dengan kegiatan mengadakan faktor-faktor produksi yang dibutuhkan untuk produksi telur. Faktor-faktor produksi tersebut terdiri dari bibit ayam ras petelur, pakan, dan vaksin. Harga faktor produksi yang fluktuatif dapat mempengaruhi biaya yang dikeluarkan oleh peternak. Sarana produksi yang telah dipenuhi oleh peternak akan digunakan untuk kegiatan usaha ternak. Kegiatan usaha ternak ayam ras petelur bertujuan untuk memperoleh keuntungan. Suatu usaha yang berkaitan dengan makhluk hidup akan menghadapi resiko kematian atau mortalitas. Adanya kesalahan kecil sekalipun dalam pemeliharaan dapat mengakibatkan meningkatnya mortalitas serta menurunnya performa ayam.. Jumlah populasi ayam petelur akan berbanding lurus dengan tingginya biayabiaya serta keuntungan yang diterima maka diperlukan evaluasi kelayakan finansial dan keuntungan peternakan ayam ras petelur untuk mengetahui apakah usaha tersebut masih layak untuk terus dikembangkan. Tujuan penelitian ini adalah mengevaluasi kelayakan finansial dan keuntungan peternakan ayam ras petelur PT SPU dan AF di Kecamatan Jati Agung Kabupaten Lampung Selatan. 


\section{METODE PENELITIAN}

Penelitian dilakukan pada usaha ternak ayam ras petelur PT SPU dan AF di Kecamatan Jati Agung Lampung Selatan. Metode penelitian yang digunakan adalah metode studi perbandingan atau comparative study. Studi perbandingan merupakan studi membandingkan dua atau lebih suatu kondisi, kejadian, kegiatan, program dan lainnya (Sukmadinata 2012).

Penelitian ini dilakukan di Kecamatan Jati Agung, Kabupaten Lampung Selatan. Lokasi penelitian dipilih secara sengaja (purposive) dengan pertimbangan bahwa Kabupaten Lampung Selatan merupakan sentra peternakan ayam ras petelur dengan populasi tertinggi di Provinsi Lampung; Kecamatan Jati Agung memiliki populasi ayam ras petelur tertinggi dibandingkan dengan kecamatan lainnya di Kabupaten Lampung Selatan; Peternakan ayam ras petelur yang dipilih adalah peternakan yang minimal telah mengalami tiga kali siklus produksi dan dapat diakses baik data maupun proses produksinya.

Berdasarkan pertimbangan tersebut, terpilih dua peternakan ayam ras petelur, yaitu PT Sumber Protein Unggul (SPU) yang berada di Desa Sumberjaya Kecamatan Jati Agung dan Ariyanto Farm (AF) yang berada di Desa Sinar Rezeki Kecamatan Jati Agung. . Waktu pengambilan data dilakukan pada Bulan Oktober sampai Desember 2018. Penelitian ini menggunakan metode analisis deskriptif kualitatif dan analisis deskriptif kuantitatif. Analisis deskriptif kuantitatif terdiri dari analisis keuntungan dan evaluasi kelayakan finansial.

Menurut Soekartawi (2006) keuntungan atau profit adalah pendapatan yang diterima oleh seseorang dari penjualan produk barang maupun jasa yang dikurangi dengan biaya-biaya yang dikeluarkan dalam membiayai produk barang maupun jasa tersebut. Pada penelitian ini, pendapatan yang dihitung berdasarkan biaya-biaya selama satu periode produksi ayam ras petelur. Perhitungan keuntungan usaha peternakan ayam ras petelur dihitung menggunakan rumus berikut:

$\Pi=$ TR-TC

Keterangan :

$\Pi=$ pendapatan usahatani

$\mathrm{TR}=$ penerimaan usahatani

$\mathrm{TC}=$ biaya usahatani
Umur proyek yang digunakan selama 15 periode (30 tahun) atas dasar umur ekonomis kandang ayam ras petelur karena usaha ternak ayam ras petelur ini sangat bergantung pada produksi ayam ras petelur tersebut. Tingkat suku bunga pinjaman yang digunakan dalam penelitian ini adalah tingkat suku bunga dari Bank Rakyat Indonesia (BRI) yang terbaru yaitu 9 persen per tahun atau 18 persen per periode (2 tahun) untuk Kredit Usaha Rakyat (KUR) Ritel.

Dalam mengukur suatu usaha layak atau tidak untuk dijalankan memerlukan beberapa kriteria kelayakan finansial. Kriteria kelayakan finansial untuk menjawab tujuan pada penelitian ini memiliki kesamaan dengan penelitian Pahlevi, Zakaria, dan Kalsum (2014) tentang analisis kelayakan usaha agroindustri kopi luwak di Kecamatan Balik Bukit Kabupaten Lampung Barat yaitu menggunakan Internal Rate of Return (IRR), Net Present Value (NPV), Payback Period (PP), Gross Benefit Cost Ratio (Gross B/C), Net Benefit Cost Ratio $($ Net B/C).

Net Present Value merupakan selisih antara present value dari benefit atau penerimaan dengan present value dari costs atau pengeluaran. Menurut Kadariah (2001), NPV dapat dirumuskan sebagai berikut:

$\mathrm{NPV}=\sum_{\mathrm{t}=1}^{\mathrm{i}} \frac{\mathrm{Bt}-\mathrm{Ct}}{(1-\mathrm{i})}$

Keterangan:
$\mathrm{Bt}=$ Benefit
$\mathrm{Ct}=$ Cost
$\mathrm{i} \quad=$ Tingkat bunga bank berlaku
$\mathrm{t} \quad=$ Tahun (waktu ekonomis)

Kriteria penilaian Net Present Value (NPV) yaitu jika NPV lebih besar dari nol pada saat suku bunga yang berlaku maka usaha ternak ayam ras petelur dinyatakan layak; Jika NPV lebih kecil dari nol pada saat suku bunga yang berlaku maka usaha ternak ayam ras petelur dinyatakan tidak layak; Jika NPV sama dengan nol pada saat suku bunga yang berlaku maka usaha ternak ayam ras petelur dinyatakan dalam posisi impas.

Internal Rate of Return (IRR) adalah suatu tingkat bunga yang menunjukkan nilai bersih sekarang (NPV) sama dengan jumlah seluruh investasi proyek. Menurut Kadariah (2001), IRR dapat dirumuskan sebagai berikut: 


$$
\mathrm{IRR}=\mathrm{i}+\left(\frac{\mathrm{NPV}_{1}}{\mathrm{NPV}_{1}-\mathrm{NPV}_{2}}\right)\left(\mathrm{i}_{2}-\mathrm{i}_{1}\right)
$$

Keterangan :

$$
\begin{array}{ll}
\mathrm{NPV}_{1} & =\text { Present Value positif } \\
\mathrm{NPV}_{2} & =\text { Present Value negative } \\
\mathrm{i}_{1} & =\text { discount faktor, jika NPV }>0 \\
\mathrm{i}_{2} & =\text { discount faktor, jika NPV }<0
\end{array}
$$

Kriteria penilaian Internal Rate of Return (IRR):yaitu jika IRR lebih besar dari tingkat suku bunga yang berlaku maka usaha ternak ayam ras petelur dinyatakan layak; Jika IRR lebih kecil dari tingkat suku bunga yang berlaku maka usaha ternak ayam ras petelur dinyatakan tidak layak; Jika IRR sama dengan tingkat suku bunga yang berlaku maka usaha ternak ayam ras petelur dinyatakan dalam posisi impas.

Net Benefit Cost Ratio (Net B/C) diperoleh dari perbandingan antara net benefit yang telah didiscount positif dengan net benefit yang telah didiscount negatif. Menurut Kadariah (2001), Net $\mathrm{B} / \mathrm{C}$ dapat dirumuskan sebagai berikut :

Net $B / C=\frac{\sum_{t=0}^{\mathrm{n}} \frac{\mathrm{Bt}-\mathrm{Ct}}{(1+\mathrm{i})^{\mathrm{t}}}}{\sum_{\mathrm{t}=0}^{\mathrm{n}} \frac{\mathrm{Ct}-\mathrm{Bt}}{(1+\mathrm{i})^{\mathrm{t}}}}$

\section{Keterangan :}

$\begin{array}{ll}\mathrm{Net} \mathrm{B} / \mathrm{C} & =\text { Net Benefit Cost Ratio } \\ \mathrm{Bt} & =\text { Benefit atau penerimaan bersih } \\ \mathrm{Ct} & =\text { Cost atau biaya pada tahun } \mathrm{t} \\ \mathrm{i} & =\text { Tingkat bunga } \\ \mathrm{t} & =\text { Bulan (waktu ekonomis) }\end{array}$

Kriteria penilaian dalam analisis ini yaitu jika Net $\mathrm{B} / \mathrm{C}$ lebih besar dari satu, maka usaha ternak ayam ras petelur dinyatakan layak; Jika Net B/C lebih kecil dari satu, maka usaha ternak ayam ras petelur dinyatakan tidak layak; Jika Net B/C sama dengan satu, maka usaha ternak ayam ras petelur dinyatakan dalam posisi impas.

Gross Benefit Cost Ratio (Gross B/C) diperoleh dari perbandingan antara penerimaan manfaat dari suatu investasi (gross benefit) dengan biaya yang telah dikeluarkan (gross cost).

Adapun kriteria penilaian dalam analisis ini yaitu jika Gross B/C lebih besar dari satu maka usaha ternak ayam ras petelur dinyatakan layak; Jika Gross B/C lebih kecil dari satu maka usaha ternak ayam ras petelur dinyatakan tidak layak; Jika Gross B/C sama dengan satu maka usaha ternak ayam ras petelur dinyatakan dalam posisi impas.
Menurut Kadariah (2001) Gross B/C dapat dirumuskan sebagai berikut:

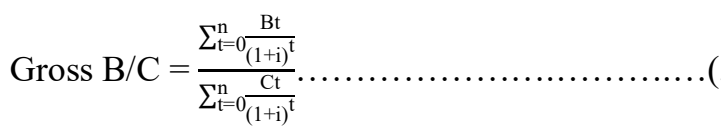

Keterangan :

$$
\begin{array}{ll}
\text { Gross B/C } & =\text { Gross Benefit Cost Ratio } \\
\mathrm{Bt} & =\text { Benefit atau penerimaan bersih } \\
\mathrm{Ct} & =\text { Cost atau biaya pada tahun } \mathrm{t} \\
\mathrm{i} & =\text { Tingkat bunga } \\
\mathrm{t} & =\text { Bulan (waktu ekonomis) }
\end{array}
$$

Payback Period (PP) merupakan penilaian investasi suatu proyek yang didasarkan pada pelunasan biaya investasi berdasarkan manfaat bersih dari suatu proyek. Secara matematis Payback Period dapat dirumuskan sebagai berikut (Kadariah 2001):

$\mathrm{PP}=\frac{\mathrm{K}_{0}}{\mathrm{~A}_{\mathrm{b}}}$

$$
\begin{aligned}
& \text { Keterangan : } \\
& \mathrm{PP} \quad=\text { Tahun pengembalian investasi } \\
& \mathrm{K}_{0} \quad=\text { Investasi awal } \\
& \mathrm{A}_{\mathrm{b}} \quad=\text { Manfaat (benefit) }
\end{aligned}
$$

Kriteria penilaian Payback Period yaitu jika Payback Period lebih pendek dari umur ekonomis kandang, maka usaha ternak ayam ras petelur dinyatakan layak, sedangkan jika Payback Period lebih lama dari umur ekonomis kandang, usaha ternak ayam ras petelur dinyatakan tidak layak.

\section{GAMBARAN UMUM LOKASI PENELITIAN}

\section{PT SPU}

Peternakan ayam ras petelur PT SPU didirikan pada tahun 1997 dan berlokasi di Desa Sumberjaya Kecamatan Jati Agung Kabupaten Lampung Selatan. Usaha ternak ini memiliki 46 kandang yang terdiri dari 37 kandang produksi atau layer, 7 kandang grower, dan 2 kandang starter. Selain itu, usaha ternak ini memiliki kapasitas populasi maksimum sebanyak 100.000 ekor dengan dengan kapasitas yang terisi sebanyak 60.480 ekor. Usaha ternak ini juga memiliki pergudangan yang terdiri dari gfudang pakan, gudang telur, dan gudang peralatan serta dilengkapi dengan satu ruang administrasi. Usaha ternak ini terletak 500 meter dari pemukiman penduduk. 


\section{AF}

Peternakan ayam ras petelur AF didirikan pada tahun 1997 dan berlokasi di Desa Sinar Rezeki Kecamatan Jati Agung Kabupaten Lampung Selatan. Peternakan ini memiliki kapasitas populasi sebanyak 30.000 ekor dengan kapasitas yang terisi pada saat ini sebanyak 19.600 ekor. Usaha ternak ini memiliki 15 kandang yang terdiri dari 12 kandang produksi atau layer, 2 kandang grower, dan 1 kandang starter. Selain itu, usaha ternak ini juga memiliki pergudangan yang terdiri dari gudang pakan, gudang telur, dan gudang peralatan.

\section{HASIL DAN PEMBAHASAN}

\section{Biaya Investasi Awal Usaha Ternak}

Biaya investasi awal terdiri dari biaya pembelian lahan, pembangunan kandang, pembangunan gudang, dan peralatan penunjang kandang. Biaya investasi awal yang dikeluarkan PT SPU dan AF akan disajikan pada Tabel 1 .
Berdasarkan Tabel 1 biaya pembelian lahan dan pembangunan kandang merupakan biaya investasi awal yang memiliki persentase terbesar atas total biaya investasi awal, masing-masing sebesar 28 persen dan 64 persen pada PT SPU serta 33 persen dan 61 persen pada usaha ternak AF.

Biaya investasi awal yang dikeluarkan oleh PT SPU lebih besar, yaitu Rp7.174.200.000,00 dibandingkan dengan biaya investasi awal usaha ternak AF yaitu sebesar Rp2.207.410.000,00. Hal tersebut dikarenakan usaha ternak PT SPU membutuhkan lebih banyak kandang serta peralatannya daripada usaha ternak $\mathrm{AF}$.

\section{Biaya Operasional Usaha Ternak}

Biaya operasional adalah biaya yang digunakan oleh usaha ternak untuk menjalankan usahanya. Biaya operasional terdiri dari biaya pembelian bibit, pakan, vaksin, tenaga kerja, listrik, gas, egg tray, dan desinfektan. Biaya operasional pada usaha ternak PT SPU dan AF dapat dilihat pada Tabel 2.

Tabel 1. Biaya investasi awal pada usaha ternak PT SPU dan AF

\begin{tabular}{|c|c|c|c|c|c|c|}
\hline \multirow[b]{2}{*}{ Jenis investasi } & \multicolumn{3}{|c|}{ PT SPU } & \multicolumn{3}{|c|}{$\mathbf{A F}$} \\
\hline & $\begin{array}{l}\text { Jumlah } \\
\text { (unit) }\end{array}$ & $\begin{array}{l}\text { Harga satuan } \\
\text { (Rp/unit) }\end{array}$ & $\begin{array}{l}\text { Biaya investasi } \\
\text { (Rp) }\end{array}$ & $\begin{array}{l}\text { Jumlah } \\
\text { (unit) }\end{array}$ & $\begin{array}{l}\text { Harga satuan } \\
\text { (Rp/unit) }\end{array}$ & $\begin{array}{l}\text { Biaya investasi } \\
\text { (Rp) }\end{array}$ \\
\hline Lahan (Ha) & 5 & 400.000 .000 & 2.000 .000 .000 & 1,8 & 400.000 .000 & 720.000 .000 \\
\hline Kandang & 46 & 100.000 .000 & 4.600 .000 .000 & 15 & 90.000 .000 & 1.350 .000 .000 \\
\hline Gudang & 2 & 50.000 .000 & 100.000 .000 & 1 & 35.000 .000 & 35.000 .000 \\
\hline $\begin{array}{l}\text { Tempat pakan } \\
\text { DOC }\end{array}$ & 160 & 25.000 & 4.000 .000 & 80 & 25.000 & 2.000 .000 \\
\hline $\begin{array}{l}\text { Tempat minum } \\
\text { DOC }\end{array}$ & 80 & 25.000 & 2.000 .000 & 40 & 25.000 & 1.000 .000 \\
\hline Pemanas & 8 & 700.000 & 5.600 .000 & 4 & 700.000 & 2.800 .000 \\
\hline $\begin{array}{l}\text { Semi automatic } \\
\text { feeder }\end{array}$ & 37 & 700.000 & 25.900 .000 & 0 & 0 & 0 \\
\hline Terpal 2x6 & 16 & 70.000 & 1.120 .000 & 8 & 70.000 & 560.000 \\
\hline Lampu & 184 & 40.000 & 7.360 .000 & 60 & 40.000 & 2.400 .000 \\
\hline Talang Pakan & 2.442 & 80.000 & 195.360 .000 & 480 & 35.000 & 16.800 .000 \\
\hline Nipple drinker & 25.000 & 6.500 & 162.500 .000 & 7.500 & 6.500 & 48.750 .000 \\
\hline Ember & 40 & 15.000 & 600.000 & 12 & 15.000 & 180.000 \\
\hline $\begin{array}{l}\text { Timbangan } \\
\text { digital }\end{array}$ & 3 & 1.000 .000 & 3.000 .000 & 1 & 1.000 .000 & 1.000 .000 \\
\hline Sekop & 12 & 30.000 & 360.000 & 4 & 30.000 & 120.000 \\
\hline Tandon air & 44 & 800.000 & 35.200 .000 & 14 & 400.000 & 5.600 .000 \\
\hline $\begin{array}{l}\text { Mesin pompa } \\
\text { air }\end{array}$ & 1 & 1.200 .000 & 1.200 .000 & 1 & 1.200 .000 & 1.200 .000 \\
\hline Generator set & 1 & 30.000 .000 & 30.000 .000 & 1 & 20.000 .000 & 20.000 .000 \\
\hline Jumlah & & & $7.174 .200 .000,00$ & & & 2.207 .410 .000 \\
\hline
\end{tabular}


Tabel 2. Biaya operasional usaha ternak PT SPU dan AF selama satu periode (20 bulan)

\begin{tabular}{lrr}
\hline \multirow{2}{*}{ Jenis Biaya } & \multicolumn{1}{c}{ PT SPU } & \multicolumn{1}{c}{ AF } \\
\cline { 2 - 3 } & Total Biaya $(\mathrm{Rp})$ & Total Biaya (Rp) \\
\hline Bibit ayam ras & 544.320 .000 & 176.400 .000 \\
petelur & 18.646 .750 .400 & 6.254 .598 .800 \\
Pakan & 202.608 .000 & 65.660 .490 \\
Vaksin & 478.000 .000 & 310.000 .000 \\
Tenaga kerja & 30.000 .000 & 14.000 .000 \\
Listrik & 8.340 .000 & 4.170 .000 \\
Gas 12 Kg & 398.426 .400 & 127.833 .540 \\
Egg tray & 35.000 .000 & 10.500 .000 \\
Desinfektan & 20.343 .444 .800 & 6.962 .662 .340 \\
\hline Total Biaya & & \\
Operasional & & \\
\hline
\end{tabular}

Berdasarkan Tabel 2 dapat dilihat bahwa biaya pakan merupakan biaya operasional yang paling besar dikeluarkan oleh kedua usaha ternak ayam ras petelur dalam satu periode produksi. Persentase biaya pakan yang dikeluarkan oleh PT SPU sebesar 91,66 persen dari total biaya operasional, sedangkan biaya pakan pada usaha ternak AF sebesar 89,83 persen dari total biaya operasional.

\section{Analisis Keuntungan}

Hasil analisis keuntungan pada usaha ternak ayam ras petelur PT. SPU dan AF selama satu periode akan disajikan pada Tabel 3.

Tabel 3. Analisis keuntungan usaha ternak PT SPU dan AF selama satu periode

\begin{tabular}{lrr}
\hline \multirow{1}{*}{ Biaya } & \multicolumn{1}{c}{ PT SPU } & \multicolumn{1}{c}{ AF } \\
\cline { 2 - 3 } & \multicolumn{1}{c}{ Jumlah $(\mathrm{Rp})$} & \multicolumn{1}{c}{ Jumlah $(\mathrm{Rp})$} \\
\hline Bibit ayam & $514.080 .000,00$ & $176.400 .000,00$ \\
Pakan & $18.646 .750 .400,00$ & $6.254 .598 .800,00$ \\
Vaksin & $202.608 .000,00$ & $65.660 .000,00$ \\
Gas 12 kg & $8.340 .000,00$ & $4.170 .000,00$ \\
Egg tray & $398.426 .400,00$ & $127.833 .540,00$ \\
Mortalitas & $8.163 .000,00$ & $2.646 .000,00$ \\
\hline Biaya variabel & $19.778 .367 .800,00$ & $6.631 .308 .340,00$ \\
\hline Tenaga kerja & $478.000 .000,00$ & $310.000 .000,00$ \\
Listrik & $30.000 .000,00$ & $14.000 .000,00$ \\
Desinfektan & $35.000 .000,00$ & $10.000 .000,00$ \\
Penyusutan & $367.609 .523,81$ & $103.709 .284,88$ \\
Biaya tetap & $910.609 .523,81$ & $437.709 .284,88$ \\
\hline \multicolumn{1}{c}{ Biaya total } & $20.688 .977 .323,81$ & $7.069 .017 .624,88$ \\
\hline \multicolumn{1}{c}{ Penerimaan } & Jumlah $(\mathrm{Rp})$ & Jumlah $(\mathrm{Rp})$ \\
\hline Telur & $29.381 .388 .642,86$ & $9.630 .381 .434,79$ \\
Limbah & $146.018 .000,00$ & $43.643 .000,00$ \\
Ayam afkir & $2.680 .785 .000,00$ & $868.770 .000,00$ \\
Total & $32.208 .191 .642,86$ & $10.542 .794 .434,79$ \\
Penerimaan & $11.519 .214 .319,05$ & $3.473 .776 .809,91$ \\
\hline Keuntungan & & \\
\hline & &
\end{tabular}

Berdasarkan Tabel 3 keuntungan rata-rata usaha ternak ayam ras petelur PT SPU yang didapatkan per bulan sebesar Rp575.960.715,95 sedangkan keuntungan yang didapat oleh usaha ternak ayam ras petelur AF per bulan sebesar Rp173.688.840,50

Hasil penelitian ini sejalan dengan penelitian Aida dan Alam (2015) tentang analisis pendapatan dan kelayakan usaha peternakan ayam petelur di Desa Potoya Kecamatan Dolo Kabupaten Sigi. Pada hasil penelitian tersebut usaha ternak ayam ras petelur tergolong menguntungkan dengan keuntungan sebesar Rp1.880.725.200,00 per tahun, sedangkan pada penelitian ini keuntungan yang didapatkan oleh usaha ternak ayam ras petelur PT SPU sebesar Rp6.911.528.591,43 per tahun dan usaha ternak AF sebesar Rp2.084.266.085,95.

Dibandingkan dengan penelitian Oktaviana, Lestari, dan Indriani (2016) tentang sistem agribisnis ayam kalkun di Desa Sukoharjo Kabupaten Pringsewu Provinsi Lampung yang memiliki keuntungan sebesar Rp72.130.500,00 per bulan, usaha ternak ayam ras petelur di PT SPU dan AF lebih menguntungkan dengan keuntungan masing-masing sebesar Rp575.960.715,95 dan Rp173.688.840,50 per bulan.

\section{Evaluasi Kelayakan Finansial}

Usaha ternak ayam ras petelur yang dilakukan oleh PT SPU dan AF bertujuan untuk mendapatkan keuntungan. Berjalan atau tidaknya usaha ternak ayam ras petelur tergantung pada keuntungan yang didapatkan oleh usaha tersebut. Analisis yang digunakan untuk mengetahui kelayakan usaha ternak ayam ras petelur PT SPU dan AF adalah analisis finansial yang meliputi perhitungan $\mathrm{Net}$ Present Value (NPV), Internal Rate of Return (IRR), Gross Benefit Cost Ratio (Gross B/C), Net Benefit Cost Ratio (Net B/C), dan Payback Period (PP).

Perhitungan analisis kelayakan finansial usaha ternak ayam ras petelur PT SPU dan AF dihitung dengan metode compound factor (cf). Tingkat suku bunga pinjaman yang digunakan dalam penelitian ini adalah tingkat suku bunga dari Kredit Usaha Rakyat (KUR) Bank Rakyat Indonesia, yaitu 9 persen per tahun atau 18 persen per periode dengan umur proyek selama 30 tahun atau 15 periode produksi atas dasar umur ekonomis kandang ayam ras petelur. Hasil perhitungan analisis kelayakan finansial usaha ternak ayam ras petelur PT SPU dan AF selama satu periode produksi disajikan pada Tabel 4. 
Tabel 4. Evaluasi kelayakan finansial usaha ternak PT SPU dan AF

\begin{tabular}{lcc}
\hline \multirow{2}{*}{ Kriteria } & \multicolumn{2}{c}{ PT SPU } \\
\cline { 2 - 3 } & Hasil & Keterangan \\
\hline NPV (Rp) & $302.010 .364 .258,35$ & Layak \\
IRR & $>100 \%(\sim)$ & Layak \\
PP (periode) & $0,64(1,28$ tahun $)$ & Layak \\
Gross B/C & 1,48 & Layak \\
Net B/C & $\sim$ & Layak \\
\hline \multicolumn{1}{c}{ Kriteria } & \multicolumn{2}{c}{ AF } \\
\cline { 2 - 3 } NPV $(\mathrm{Rp})$ & $90.745 .200 .720,22$ & Keterangan \\
IRR & $>100 \%(\sim)$ & Layak \\
PP (periode $)$ & $0,90(1,80$ tahun $)$ & Layak \\
Gross B/C & 1,43 & Layak \\
Net B/C & $\sim$ & Layak \\
\hline
\end{tabular}

Berdasarkan Tabel 4 dapat dilihat hasil evaluasi kelayakan finansial usaha ternak ayam ras petelur PT SPU dan AF berdasarkan beberapa kriteria berikut:

\section{a. Net Present Value (NPV)}

Net Present Value merupakan selisih antara present value dari benefit atau penerimaan dengan present value dari costs atau pengeluaran. Berdasarkan hasil perhitungan dari penelitian ini, nilai NPV dari usaha ternak PT SPU dan AF lebih besar dari nol, masing-masing sebesar Rp 302.010.364.258,35 dan Rp 90.745.200.720,22. Hal tersebut menunjukkan bahwa usaha ternak ayam ras petelur PT SPU dan AF layak untuk dikembangkan.

\section{b. Internal Rate of Return (IRR)}

Internal Rate of Return (IRR) adalah suatu tingkat bunga yang menunjukkan nilai bersih sekarang (NPV) sama dengan jumlah seluruh investasi proyek atau dengan kata lain tingkat bunga yang menghasilkan NPV sama dengan nol. Tujuan perhitungan IRR adalah untuk mengetahui persentase keuntungan dari suatu usaha tiap bulannya. Suku bunga yang berlaku dan digunakan pada penelitian ini adalah 18 persen per periode. Jika nilai IRR dari usaha ternak ayam ras petelur PT SPU dan AF lebih besar dari tingkat suku bunga yang berlaku, maka usaha ini layak untuk dikembangkan.

Berdasarkan hasil perhitungan dari penelitian ini, nilai IRR dari usaha ternak PT SPU dan AF lebih besar dari nilai suku bunga yang berlaku, yaitu lebih dari 100 persen atau tak terhingga. Hal tersebut dikarenakan Present Value Net Benefit dari kedua usaha ternak tersebut bernilai positif semua. Hal tersebut menunjukkan bahwa usaha ternak ayam ras petelur PT SPU dan AF layak untuk dikembangkan.

\section{c. Gross Benefit Cost Ratio (Gross B/C)}

Gross Benefit Cost Ratio (Gross B/C) diperoleh dari perbandingan antara penerimaan manfaat dari suatu investasi (gross benefit) dengan biaya yang telah dikeluarkan (gross cost). Jika nilai Gross $\mathrm{B} / \mathrm{C}$ dari usaha ternak ayam ras petelur PT SPU dan AF lebih besar dari satu, maka usaha ini layak untuk dikembangkan. Berdasarkan hasil perhitungan dari penelitian ini, nilai Gross B/C dari usaha ternak PT SPU dan AF lebih besar dari satu, masing-masing sebesar 1,48 dan 1,43. Hal tersebut menunjukkan bahwa usaha ternak ayam ras petelur PT SPU dan AF layak untuk dikembangkan.

\section{d. Net Benefit Cost Ratio (Net B/C)}

Net Benefit Cost Ratio (Net B/C) diperoleh dari perbandingan antara net benefit yang telah didiscount positif dengan net benefit yang telah didiscount negatif. Jika nilai Net $\mathrm{B} / \mathrm{C}$ dari usaha ternak ayam ras petelur PT SPU dan AF lebih besar dari satu, maka usaha ini layak untuk dikembangkan. Berdasarkan hasil perhitungan dari penelitian ini, nilai Net $\mathrm{B} / \mathrm{C}$ dari usaha ternak PT SPU dan AF adalah tah terhingga $(\sim)$. Hal tersebut dikarenakan Present Value Net Benefit dari kedua usaha ternak tersebut bernilai positif semua. Hal tersebut menunjukkan bahwa kedua usaha ternak ayam ras petelur tersebut layak dikembangkan.

\section{e. Payback Periode (PP)}

Payback Period (PP) merupakan penilaian investasi suatu proyek yang didasarkan pada pelunasan biaya investasi berdasarkan manfaat bersih dari suatu proyek. Berdasarkan hasil perhitungan dari penelitian ini, nilai Payback Period dari usaha ternak PT SPU dan AF lebih pendek dari umur ekonomis kandang yaitu 30 tahun, masing-masing sebesar 0,64 periode $(1,28$ tahun) dan 0,90 periode (1,80 tahun). Hal tersebut menunjukkan bahwa usaha ternak ayam ras petelur PT SPU dan AF layak untuk dikembangkan mampu mengembalikan modal investasi sebelum periode produksi habis. Berdasarkan hasil evaluasi kelayakan finansial, usaha ternak ayam ras petelur di PT SPU dan AF menguntungkan dan layak dikembangkan. Hasil penelitian ini sejalan dengan penelitian Sunarya, Abidin, dan Kalsum (2016) 
tentang Analisis Finansial Usaha Ternak Ayam Probiotik Studi Kasus KPA Berkat Usaha Bersama Kota Metro, pada penelitian tersebut NPV bernilai positif, Net B/C Ratio bernilai lebih besar dari 1, Gross B/C Ratio lebih besar dari 1, IRR lebih besar dari suku bunga, PP lebih kecil dari umur ekonomis.

\section{KESIMPULAN}

Berdasarkan penelitian yang telah dilakukan, maka dapat disimpulkan bahwa usaha ternak ayam ras petelur PT. SPU dan AF menguntungkan dan layak untuk dikembangkan karena telah memenuhi kriteria berdasarkan perhitungan Net Present Value, Internal Rate of Return, Gross Benefit Cost Ratio, Net Benefit Cost Ratio, dan Payback Period.

\section{DAFTAR PUSTAKA}

Aida N dan Alam MN. 2015. Analisis pendapatan dan kelayakan usaha peternakan ayam petelur Hj. Sari Intan di Desa Potoya Kecamatan Dolo Kabupaten Sigi. Jurnal Agrotekbis: $\quad 3$ (6): $\quad 725-730$. http://jurnal.untad.ac.id/jurnal/index.php/ Agrotekbis/article/view/5399/4136. [19 Maret 2018].

Badan Pusat Statistik. 2017. Lampung Dalam Angka. Badan Pusat Statistik. Lampung.
Direktorat Jendral Peternakan dan Kesehatan Hewan. 2010. Telur Sumber Makanan Bergizi. http://ditjennak.pertanian.go.id. [12 Januari 2018].

Kadariah. 2001. Evaluasi Proyek Analisa Ekonomi. Lembaga Penerbit Fakultas Ekonomi. Universitas Indonesia. Jakarta.

Oktaviana E, Lestari DAH, dan Indriani Y. 2016. Sistem agribisnis ayam kalkun di Desa Sukoharjo Kabupaten Pringsewu Provinsi Lampung. $\quad$ JIIA: 4 (3): 262-268. http://jurnal.fp.unila.ac.id/index.php/JIA/ article/view/1500. [28 Desember 2018].

Pahlevi R, Zakaria WA, dan Kalsum U. 2014. Analisis kelayakan usaha agroindustry kopi luwak di Kecamatan Balik Bukit Kabupaten Lampung Barat. JIIA: 2 (1): 48-55. http://jurnal.fp.unila.ac.id/index.php/JIA/ article/view/560. [28 Desember 2018].

Soekartawi. 2006. Agribisnis Teori dan Aplikasi. Rajawali Press. Jakarta.

Sukmadinata NS. 2012. Metode Penelitian Pendidikan. PT Remaja Rosdakarya. Bandung

Sunarya BSC, Abidin Z, dan Kalsum U. 2016. Analisis finansial usaha ternak ayam probiotik studi kasus KPA Berkat Usaha Bersama Kota Metro. JIIA: 4 (1): 15-23. http://jurnal.fp.unila.ac.id/index.php/JIA/ article/view/1210. [28 Desember 2018]. 